\title{
Impact of Globalization on Entrepreneurship in Developing Countries
}

\author{
Prof. Dr. Ahmet Incekara (Istanbul University, Turkey) \\ Ph.D. Candidate Mesut Savrul (Çanakkale Onsekiz Mart University, Turkey)
}

\begin{abstract}
Contemporarily, globalization is regarded as one of the most comprehensive forces that shape the modern world. It led to major increases in worldwide trade and exchanges in an increasingly open, integrated, and borderless international economy. The participation of developing countries in the globalization process created an opportunity for them to better utilize their comparative advantages through entrepreneurs. Entrepreneurship is often associated with job creation, wealth creation, innovation and its related welfare effects. Thus it is generally credited with economic development instrument especially for developing countries. In this regard, impact of globalization on entrepreneurship in developing countries is investigated in the study. Entrepreneurship and globalization data is collected from KOF Index of Globalization and Global Entrepreneurship Monitor. The data of the countries classified by UNDP Country Classification System. Comparison of the data has shown that globalization has a positive impact on entrepreneurial activities and although entrepreneurship levels are rising all over the world it is more effective in developing countries than developed ones and emerging markets in the last decade due to the increase in the globalization process.
\end{abstract}

\section{Introduction}

Globalization is the result of increasing integration of economies around the world, particularly through the movement of goods, services, and capital across borders which also led to the movement of labour and technology across international borders. The term became more common in the 1980s, reflecting technological advances that made it easier and quicker to complete international transactions both trade and financial flows. Globalization refers to an extension beyond national borders of the same market forces that have operated for centuries at all levels of human economic activity, village markets, urban industries, or financial centres.

Globalization is the tendency of investment funds and businesses to move beyond domestic and national markets to other markets around the globe, allowing them to become interconnected with different markets. Accordingly globalization provides organizations a superior competitive position with lower operating costs, to gain greater numbers of products, services and consumers. This approach to competition is gained via diversification of resources, the creation and development of new investment opportunities by opening up additional markets, and accessing new raw materials and resources(İncekara and Savrul, 2012).

Globalization has begun to dismantle the barriers that traditionally segregated local business opportunities and local firms from their international counterparts. Local markets are becoming integral parts of broader, global markets. Consequently, internationally oriented entrepreneurs can now view a much broader range of opportunities and competitive modes, unrestricted by national boundaries. In this integrating global environment, entrepreneurs and emerging businesses face both new opportunities, and formidable new challenges (Etemad and Wright, 2003).

Entrepreneurship is often regarded as an important component in stimulating economic growth, innovation, competitiveness, and alleviating poverty in developing countries. In this framework whether globalization phase has any impacts on level of entrepreneurship come into question.

\section{Globalization}

The advancement of science and technologies has greatly reduced the cost of transportation and communication, making economic globalization possible. Nowadays, ocean shipping cost is only a half of that in the year 1930, the current airfreight one-sixth, and telecommunication cost one percent. The price level of computers in 1990 was only about one percent of that in 1960, and this price level in 1998 reduced again by about eighty percent. This kind of time and space compression effect of technological advancement greatly reduced the cost of international trade and investment, thus making it possible to organize and coordinate global production (Shangquan, 2000:1).

Clearly, globalization has something to do with increased integration of the world society, with an emphasis on increased economic integration. It also involved with businesses changing their reference point thinking globally rather than locally and technological change. However despite the concept's being new none of these elements have existed since, at least the Second World War. The economic integration of world economies has been ongoing over the last fifty years, as countries have worked through GATT and the WTO to reduce trade restrictions. In the 1960s and 1970s there was major discussion of the growth of the multinational corporation as businesses changed their reference point from domestic to international (Colander, 2002:1). 
By the 1980s, the dynamics of globalization can be explained by broader and interacting movements such as innovation and institutional change which are both internal and external to the economies. Since 2000, the arrival of new players has amplified the trends at work and caused them to converge defining a new phase of globalization (Miotti and Sachwald, 2006 :9). Today globalization is seen as one of the most comprehensive force that shape the modern world. The concept is increasing its presence due to the weakening of the economic and national structures of societies. As it is defined by the concepts such as "new economy" and "post-industrial production", globalization created a radical transformation in the world economy by focusing on the production of services rather than goods. This development led qualified human resources to turn into the most important factor of production (İncekara and Savrul, 2011:6). This transformation resulted in globalization to boost its strength and potency in the world.

Globalization led to major increases in worldwide trade and exchanges in an increasingly open, integrated, and borderless international economy. There has been remarkable growth in such trade and exchanges, not only in traditional international trade in goods and services, but also in exchanges of currencies, in capital movements, in technology transfer, in people moving through international travel and migration, and in international flows of information and ideas (Intriligator, 2003:2). Financial and industrial globalization is increasing substantially and is creating new opportunities for both developed and developing countries. However developed and developing countries basically have different expectations in this process. While integration and globalization of the developing countries mean of initiating industrialization, it means increase of the rate of industrialization for the developed countries (İncekara and Savrul, 2012:24). For developing countries, this has led to both positive and negative effects such as increased standard of living, access to new markets, widening disparity in incomes, decreased employment.

The concept of globalization received attention from researchers because of its generally recognized importance as an economic factor, but seemingly also due to of the lack of a generally accepted definition. Although globalization has become a widely used term, equally widespread is its related misconception. An aim for academic research on globalization should be describing the relationship between visible elements and the broad term globalization, as this will lead to awareness (Vinig and Kluijver 2007:6). In this framework, when the economic channels that the globalization penetrate the economy questioned the concepts such as innovation and entrepreneurship come forward.

\section{Entrepreneurship in Globalization Phase}

Although entrepreneurship isn't a new term for the developed countries, economical infrastructure of most of them formed due to it and at least in practice, it can be said to be rather new in developing countries. Due to lack of capital accumulation, qualified human resources and social and political substructure, the term remained a theatrical concept until recently and it can be accepted that globalization phase launched the golden era of entrepreneurship especially in developing countries.

The participation of developing countries in the globalization process created an opportunity for them to better utilize their comparative advantages, introduce advanced technologies, foreign capital and management experience. It is also favourable for eliminating monopolistic behaviours and strengthening market competition (Shangquan, 2000:4-5) and entrepreneurs have played a major role in initiating the process.

\section{Entrepreneurship and Economic Development}

The role of entrepreneurship in economic development is the subject of much interest to academic and policy circles alike. Entrepreneurship is often credited with many positive changes in developing countries. At the very least, it is associated with job creation, wealth creation, innovation and its related welfare effects. A strong small business sector and entrepreneurship are generally linked to a strong economy (Desai, 2009:1). Developing countries are beginning to focus on their business environments and creating an economic space which is conducive to private enterprise, after failed attempts at development through import substitution and infant industry protection programs and somewhat mixed results from export promotion strategies. Indeed, the promotion of entrepreneurship and the promulgation of small and medium sized enterprise policy has become an important development prescription in recent years. Entrepreneurship policy, then, joins a list which includes reforms to countries' macro-economic, exchange rate, trade and industrial policies and improvements in governance (Acs and Virgill, 2009:2-3).

Development economists distinguish three major stages of development in which entrepreneurship play a crucial role (Acs, 2006:99-100). 

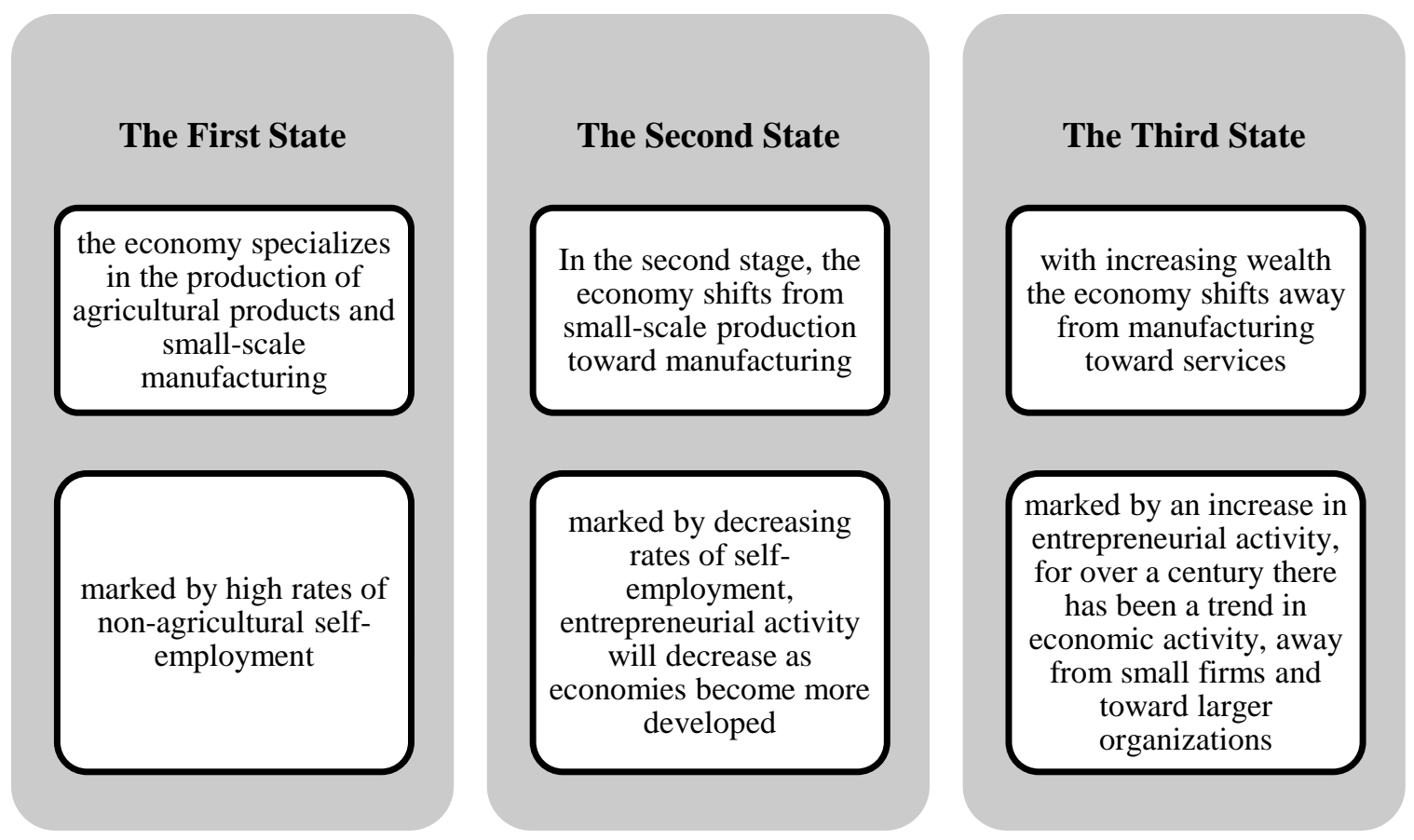

Fostering entrepreneurship is widely perceived to be a critical policy agenda to expand employment and earning opportunities and to reduce poverty. Sound macroeconomic conditions and business environment including infrastructure, regulation, and legal environment have typically been emphasized to increase entrepreneurial activities and create jobs. While these remain relevant, in developing countries, increasing attention is being paid to the role of labour policies that aim to reduce constraints and enhance productivity among the self employed and small scale entrepreneurs. This is particularly pressing in developing countries where wage and salary employment is limited and the majority of jobs are created and operated in self employment (Cho and Honorati 2013:1).

\section{Entrepreneurship in Developing Countries}

While providing more development opportunities for developing countries, the globalization process is also posing enormous risks. Economic globalization has developing countries' risks of being concussed by unfavourable external factors. Under open economic conditions, the conflict between the realization of external economic equilibrium and that of internal economic equilibrium is a great constraint on the macroeconomic policies of developing countries, weakening their capacity of macroeconomic control and regulation (Shangquan, 2000:4-5). In this respect although entrepreneurship is not a precise cure for economic development for developing countries, it can boost economic development when practiced conveniently.

Kirzner (1973) distinguishes his view of entrepreneurship, which he envisions as equilibrating, with Schumpeter's (1934), which he depicts as disequilibrating. Schumpeter's entrepreneur acts to disturb an existing equilibrium situation. The entrepreneur is pictured as initiating change and generating new opportunities. More recent studies have confirmed this result for most developing countries in the 1970 and 1980s. The empirical evidence clearly showed that the firm-size distribution in developed countries began to shift away from larger corporations and toward entrepreneurial activity (Acs, 2006:99-100).

Some distinctive attributes of entrepreneurship in developing countries appear to improve the probability of success for growth-oriented firms, while others appear to hold back these firms (Lingelbach et al, 2005:3-6);

- Opportunity

- Opportunities for entrepreneurs in developing countries are broader in scope than in developed markets, allowing firms to pursue a portfolio approach to strategy that can efficiently manage the higher levels of business and market risk.

- Entrepreneurs in developing countries face a different set of circumstances than their counterparts in developed economies.

- Emerging markets lack a stable of mature markets and the consistency that such markets offer. Consequently, the opportunity for entrepreneurship in emerging markets is pervasive.

- Financial Resources

- While entrepreneurial opportunities are broader and resultant strategies are naturally self-hedging in developing countries, limited personal and family savings and an absence of financial innovation severely limits the growth prospects of promising start-ups in developing countries. 
- Apprenticeship and Human Resources

- Technical, industry-specific training is an important component in the creation of globally competitive firms.

- These firms often form into geographically focused industrial clusters which led to emergence of globally competitive industries in developing countries.

\section{Does Globalization Impact Entrepreneurship?}

The globalization of economies has heightened the importance of entrepreneurial action for creating wealth. Demographic shifts, liberalization of national economies and attendant markets, institutional and state failures, and technological advances have combined to increase the calls for more social consciousness within businesses (Zahra et al, 2008:118). Audretsch (2007) argues that globalization has led to a shift from an industrial to an entrepreneurial model of production. Globalization is interpreted as a level shock in the supply of unskilled labour to the world economy, a decrease in the level of political risk associated with foreign direct investment, and the widespread diffusion of ICT. References to the impact of country's level of globalization on its level of entrepreneurship can be found in based on comparing data measuring entrepreneurship and globalization.

The global business environment is changing dramatically. Traditionally, competition in international markets has been the realm of large companies, while smaller businesses remained local or regional in scope. However, the removal of government-imposed barriers that segregated and protected domestic markets and recent technological advances in manufacturing, transportation and telecommunications allows even the smallest firms access to customers, suppliers and collaborators around the world. Economic growth and innovation, both domestically and internationally, are fuelled increasingly by small companies and/or entrepreneurial enterprises (Etemad and Wright, 2003:3).

Macroeconomical alterations in a country due to globalization are likely to be experienced differently by SMEs than large companies. SMEs have to operate within the macroeconomic environment of domestic and international markets, and as such are affected by changes in this environment. Among others, two socialeconomic results of an increased level of globalization in a country are enlarged inequality enhanced consumer demand for variety. Both of these have been marked as determinants for higher levels of entrepreneurship in a country (Vinig and Kluijver 2007:12).

\subsection{Competitive patterns}

McKinnon (2003) cited Namiki's four competitive patterns illustrate how firms can maintain competitive advantage under globalisation as follows;
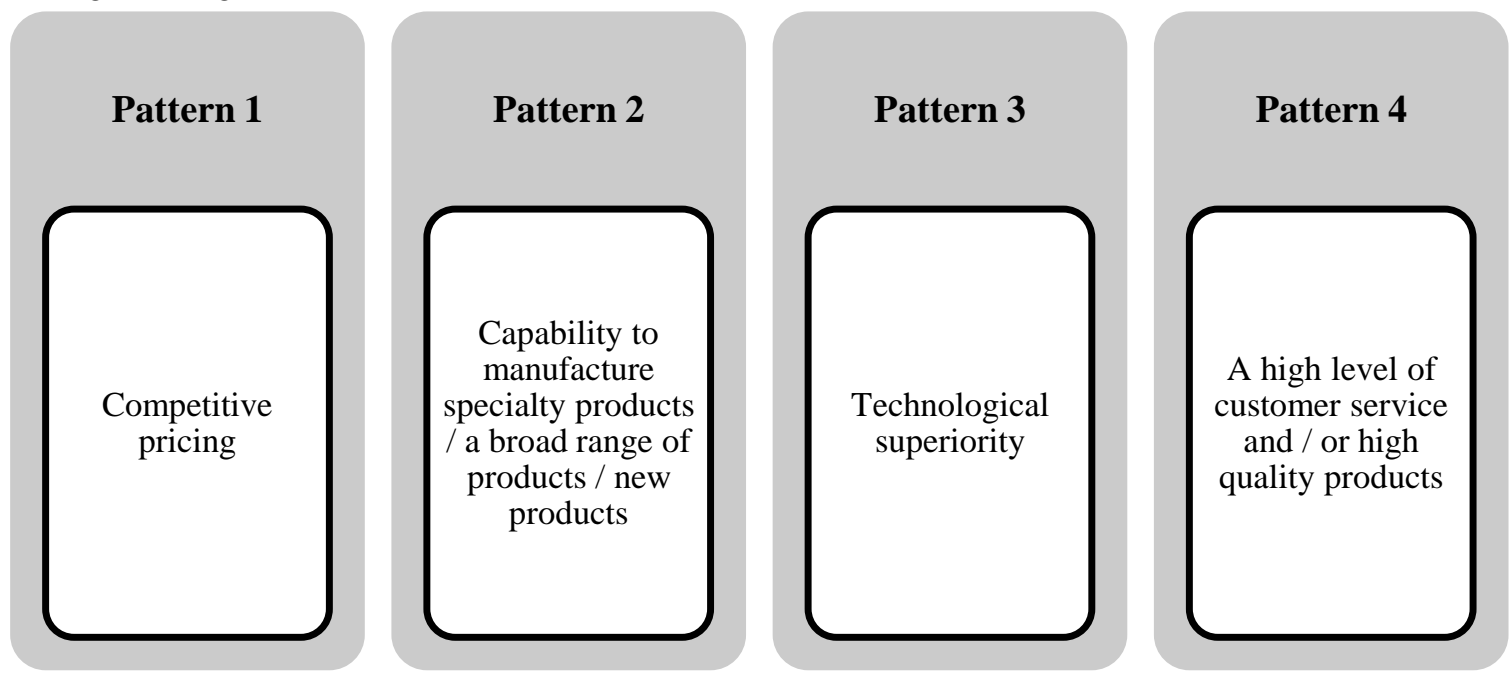

The most important factors in the globalization of entrepreneurs are technology and the falling costs of communications. The success of entrepreneurship is driven by technological changes. These changes have democratized entrepreneurship and entrepreneurs can come from anywhere in the world and can reach customers anywhere from the day they open their doors (Haar, 2012:2). In this regard the patterns can provide insights for the current situation of developing countries. Although developed countries precede in technological superiority and high level of customer service and / or high quality products patterns since most of their production facilities have been settled in developing countries by entrepreneurship and technological spillovers, developed countries gained too much competitive advantage in the last decade. 


\subsection{Development Level Comparison of Globalization and Entrepreneurship}

Before glancing at how globalization affected entrepreneurship levels of the countries, it would be beneficial to check out the comparison of entrepreneurship figures of developed, developing and emerging economies using Global Entrepreneurship Monitor data.

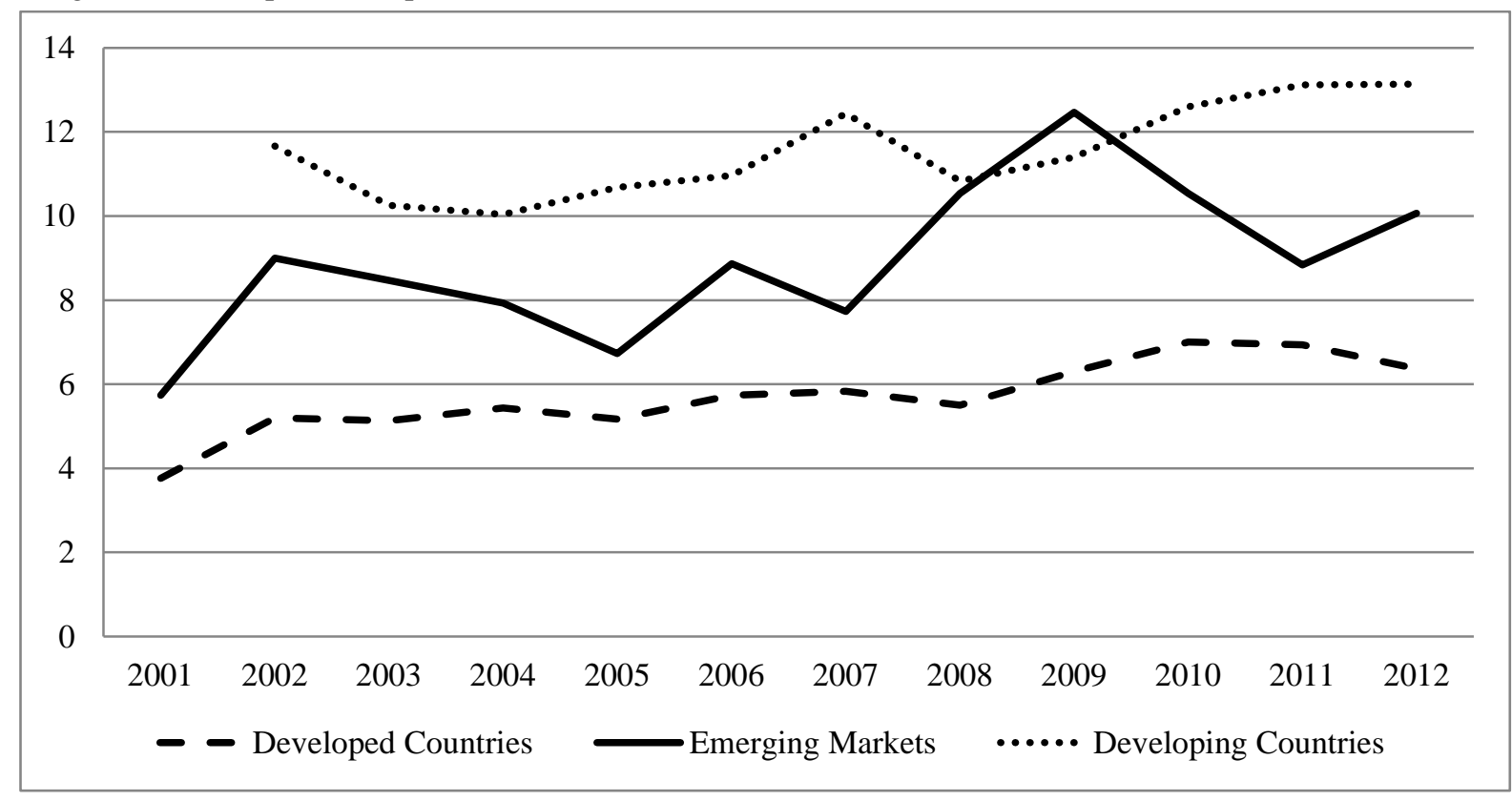

Figure 1. Established Business Ownership 2001-2012 Source: Global Entrepreneurship Research Association (2013), "Global Entrepreneurship Monitor", London Business School, UK.

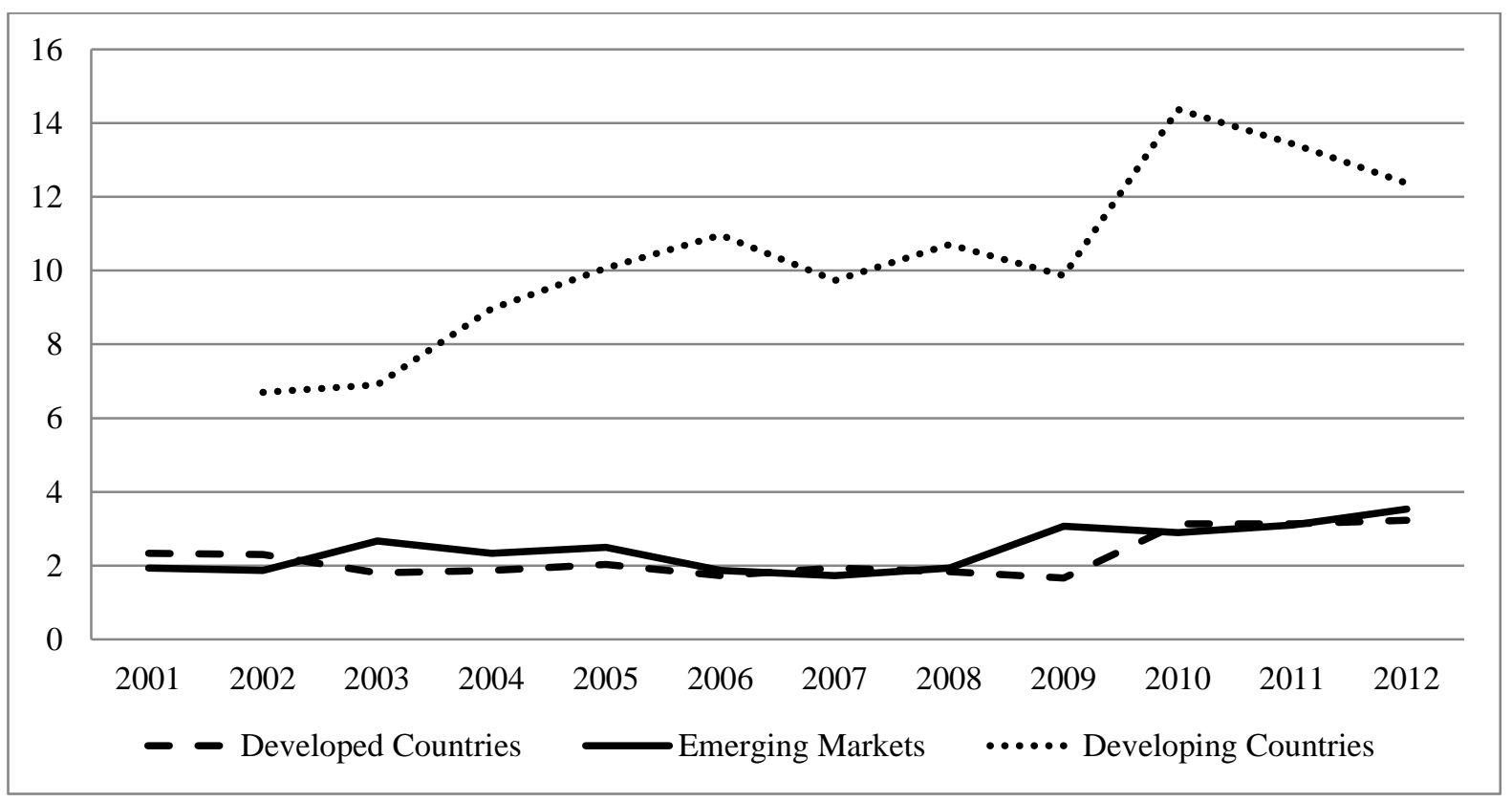

Figure 2. Informal Investors Rate 2001-2012 Source: Global Entrepreneurship Research Association (2013), "Global Entrepreneurship Monitor", London Business School, UK. 


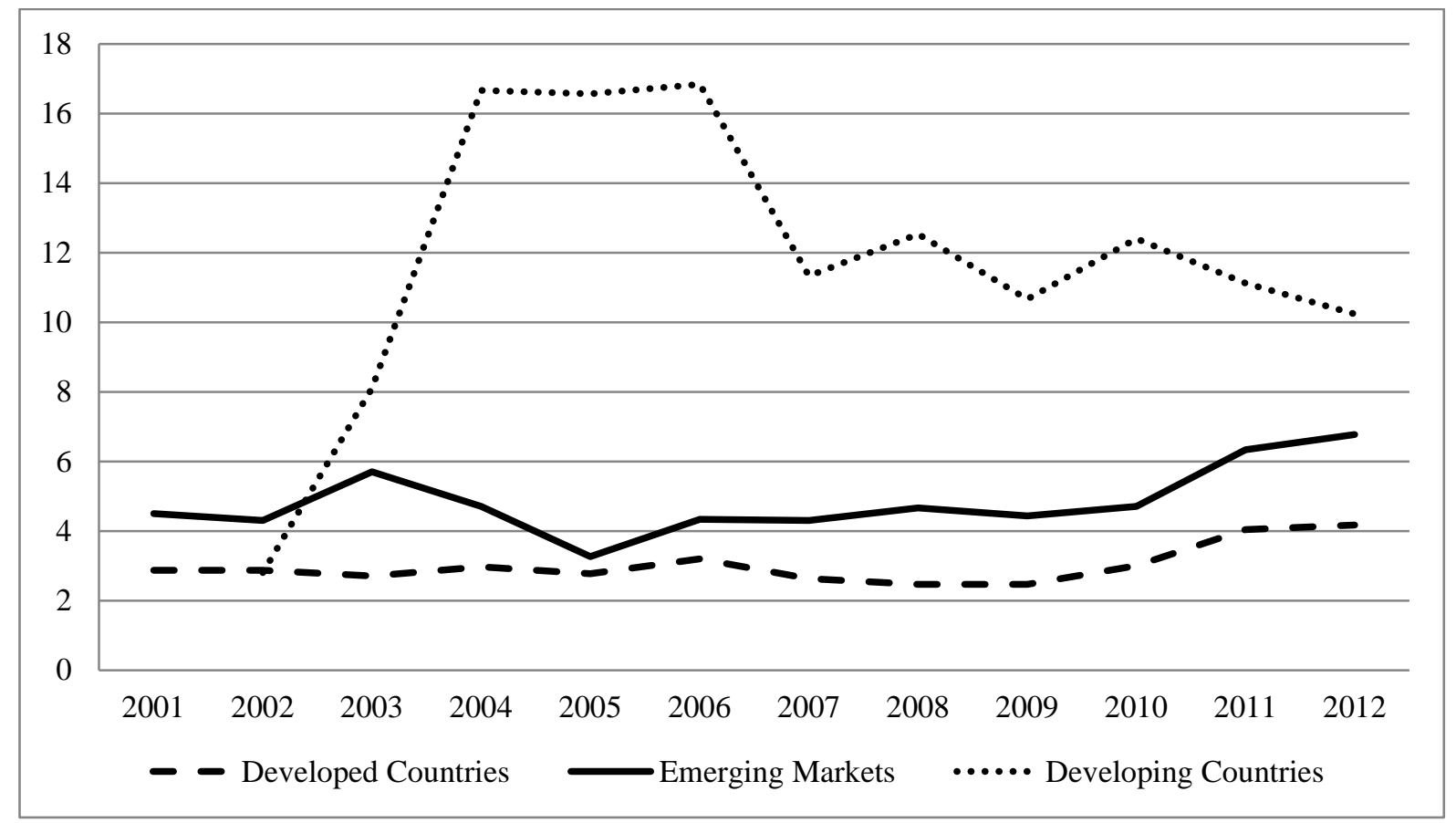

Figure 3. Nascent Entrepreneurship Rate 2001-2012 Source: Global Entrepreneurship Research Association (2013), "Global Entrepreneurship Monitor", London Business School, UK.

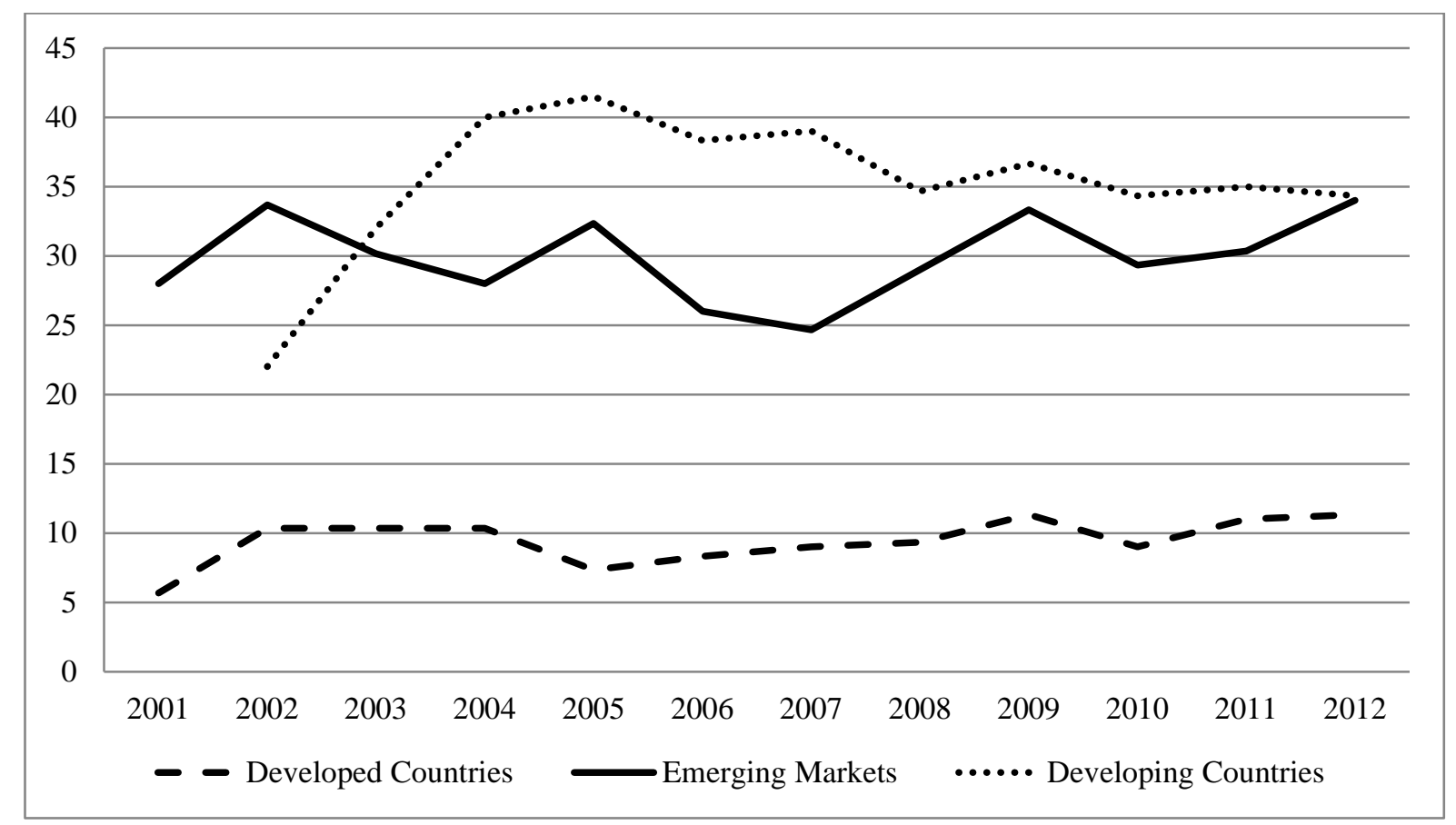

Figure 4. Necessity-Driven Entrepreneurial Activity 2001-2012 Source: Global Entrepreneurship Research Association (2013), "Global Entrepreneurship Monitor", London Business School, UK. 


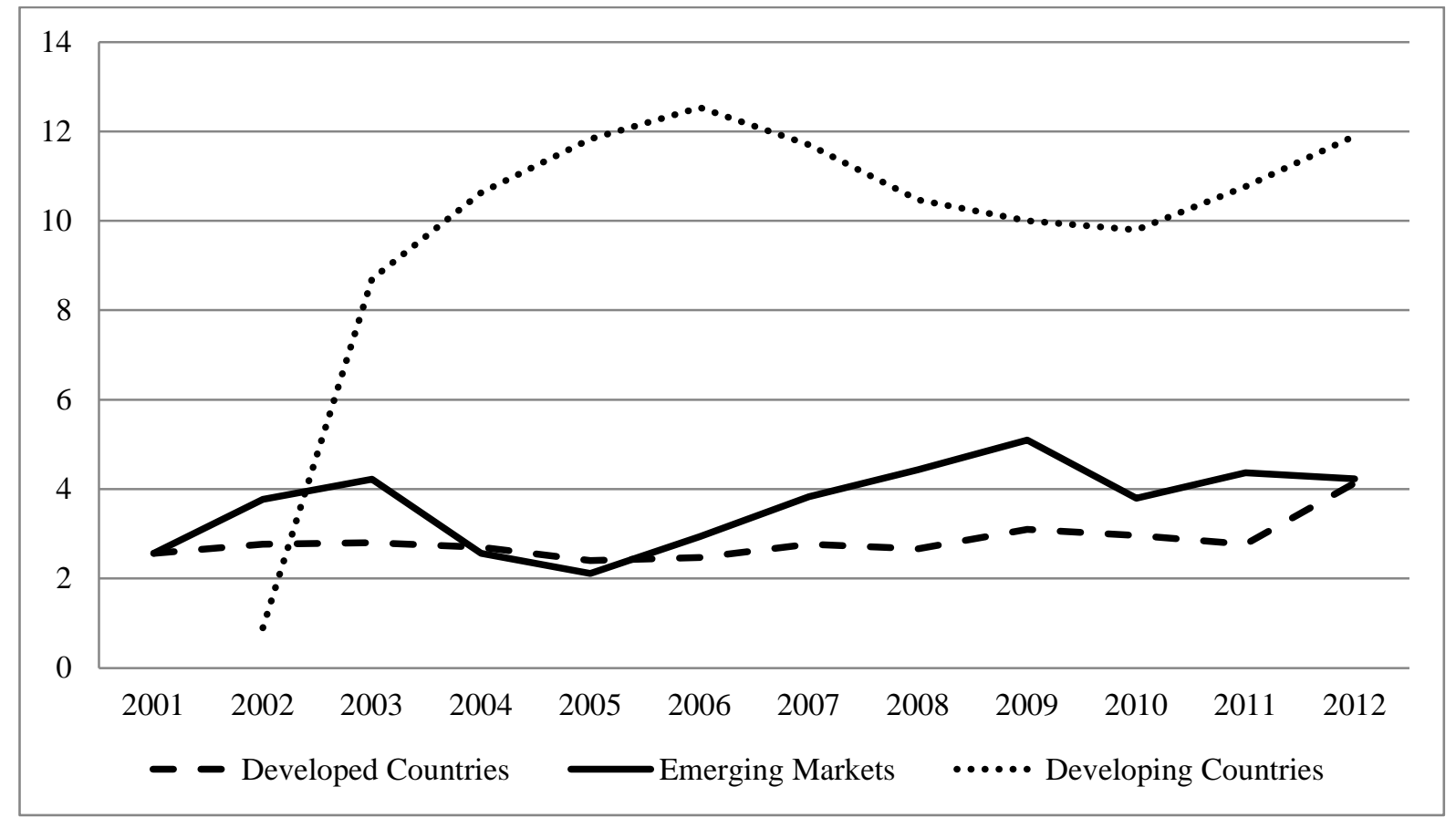

Figure 5. New Business Ownership Rate 2001-2012 Source: Global Entrepreneurship Research Association (2013), "Global Entrepreneurship Monitor", London Business School, UK.

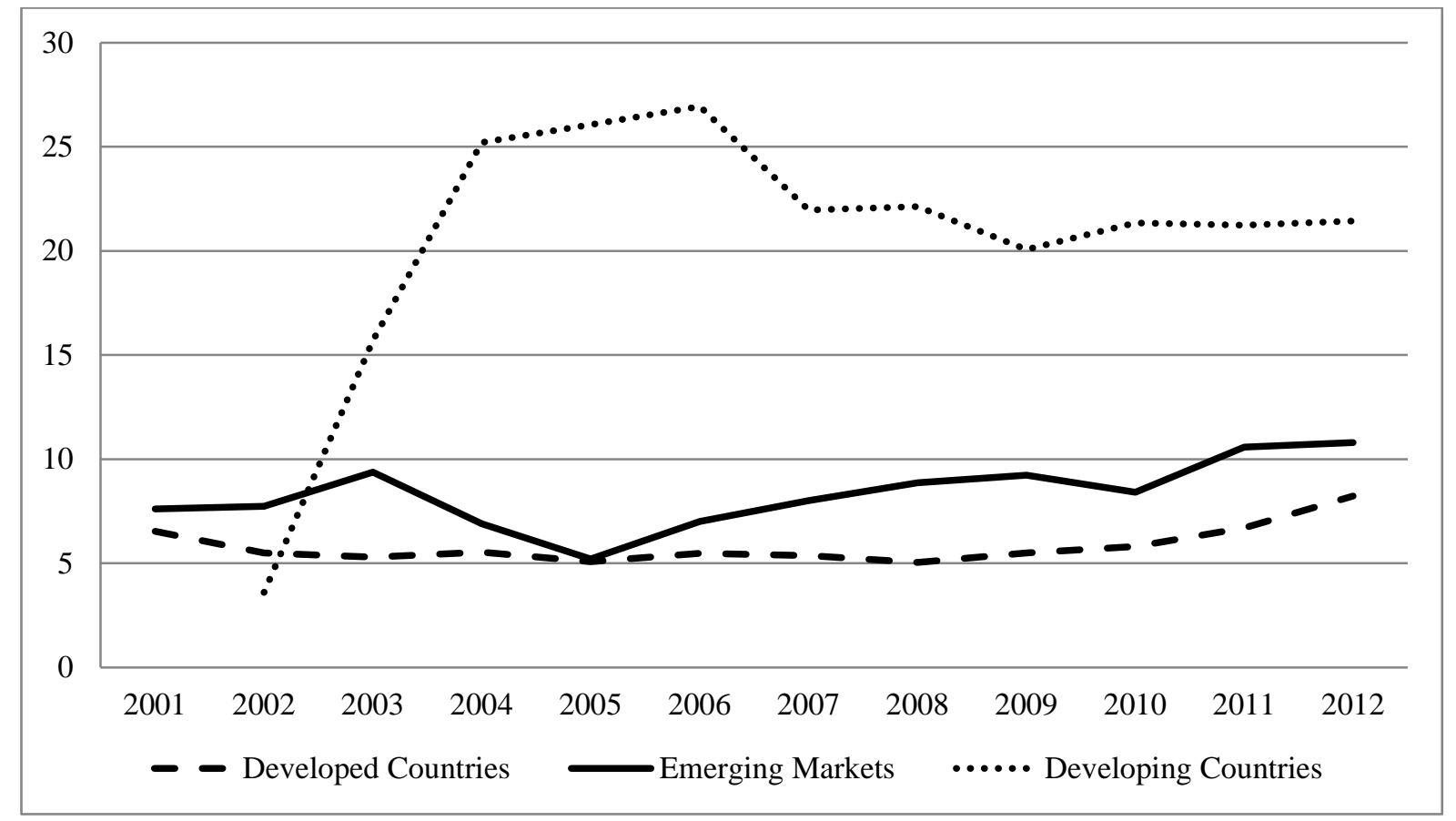

Figure 6. Total Early-Stage Entrepreneurial Activity (TEA) 2001-2012 Source: Global Entrepreneurship Research Association (2013), "Global Entrepreneurship Monitor", London Business School, UK.

The figures visualize that entrepreneurial activities are in a rising trend all over the world. However it is apparent that entrepreneurship levels of developing countries are far more active than both emerging markets and developed countries. Developing countries have established business ownership values more than $200 \%$ of developed ones; they have 500\% more informal investors rate; $600 \%$ more nascent entrepreneurship rate; $350 \%$ more necessity-driven entrepreneurial activity rate; $400 \%$ more new business ownership rate and $400 \%$ more total early-stage entrepreneurial activity on the average. It also can be seen that emerging markets is the second in the list in all of the figures. Another remarkable issue is that the Global Economic Crisis of 2008-2009 had negative impact on entrepreneurial activities of all the countries but the Crisis hit the activities of developing countries worse. 


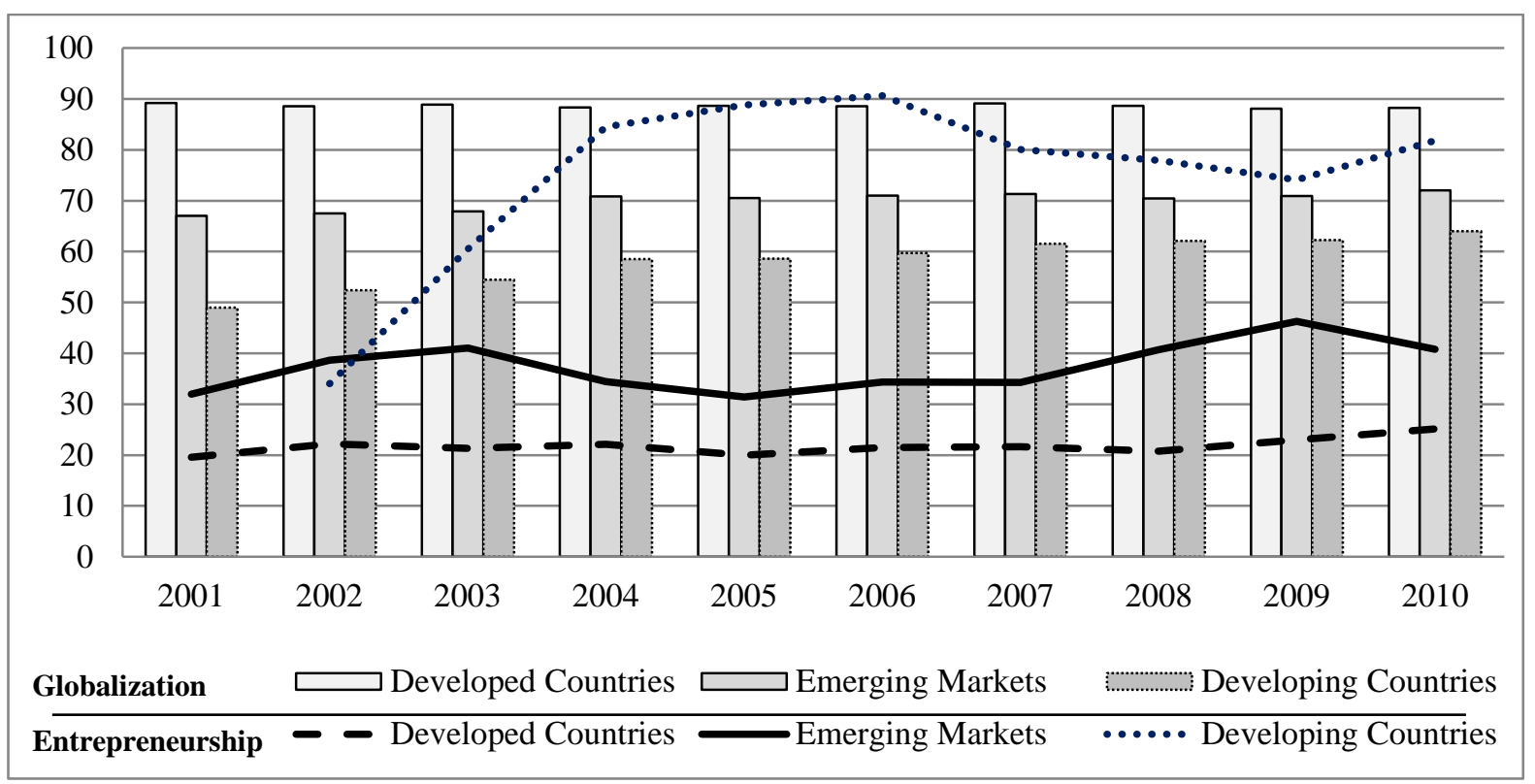

Figure 7. Development Level Comparison of Globalization \& Entrepreneurship 2001-2010 Source: Global Entrepreneurship Research Association (2013), "Global Entrepreneurship Monitor" , London Business School, UK; KOF Swiss Economic Institute, (2013), "KOF Index of Globalization", Zurich.

When overall Global Entrepreneurship Monitor score of the countries compared with the globalization index, it can be said that the values almost overlap. In the last decade globalization index of the developed countries had no change at all and their entrepreneurship level had a little rise. On the other hand emerging markets and particularly developing countries gained too much from globalization phase in terms of entrepreneurship. While their globalization index increased 34\%, their entrepreneurship approximately increased $238 \%$.

\section{Conclusion and Suggestions}

Globalization led to major increases in worldwide trade and exchanges in an increasingly open, integrated, and borderless international economy. Developing countries have left no stone unturned to achieve economic development and growth and globalization process have created an opportunity for them to utilize their comparative advantages, introduce advanced technologies, foreign capital and management experience. It is also favourable for eliminating monopolistic behaviours and strengthening market competition.

With the rise of globalization, entrepreneurial global start-ups have emerged in developing countries which is associated with job creation, wealth creation, innovation and its related welfare effects. Indeed, the promotion of entrepreneurship and the promulgation of small and medium sized enterprise policy has become an important development prescription in recent years in this countries.

In this study we questioned how globalization process diversify the development of entrepreneurship at a development level classification. Global Entrepreneurship Monitor and KOF Index of Globalization data is used to investigate the query. The figures displayed that entrepreneurial activities are for more operative in developing countries than both emerging markets and developed economies. Also a positive relationship between the development of a country's level of globalization and the rate of entrepreneurship.

It can be concluded that the distinctive economic nature of developing countries and developed ones provide broader opportunities for the entrepreneurs and they are currently at the centre of attention for both local and global enterprises. The limitation of the study is the lack of observations about the subject. Since many of the developing countries and even some of developed ones don't have sufficient entrepreneurship information at the moment the study can't be expanded further but it can be broadened with quantitative analyses when sufficient observations are obtained in the future.

\section{References}

- $\quad$ Acs, Z. (2006), "How Is Entrepreneurship Good for Economic Growth?" Mitpress journals, <http://www.mitpressjournals.org/doi/pdf/10.1162/itgg.2006.1.1.97>.

- $\quad$ Acs, Z. J., Preston, L. (1997), "Small and Medium-Sized Enterprises, Technology, and Globalization: Introduction to a Special Issue on Small and Medium-Sized Enterprises in the Global Economy", Small Business Economics, 9, pp. 1-6. 
- $\quad$ Acs, Z. Virgill, N. (2009), "Entrepreneurship in Developing Countries", Jena Economic Research Papers, 023.

- Cho Y., Honorati M. (2013), "Entrepreneurship Programs in Developing Countries: A Meta Regression Analysis", IZA, DP No. 7333.

- Colander, D. (2002), "Globalization and Economics", Middlebury College, Economics Discussion Paper No. 02-35, Middlebury, Vermont.

- Desai, S. (2009), "Measuring Entrepreneurship in Developing Countries", UNU-WIDER, Research Paper No. 2009/10.

- Etemad, H., Wright, R.W. (2003), "Globalization and Entrepreneurship: Policy and Strategy Perspectives", Edward Elgar Publishing, UK.

- Global Entrepreneurship Research Association (2013), "Global Entrepreneurship Monitor" , London Business School, UK.

- Haar, J. (2012), "Globalization and Entrepreneurship in Latin America", The Impact of Globalization on Latin America Task Force, Center For hemispheric Policy, Florida.

- İncekara, A., Savrul, M. (2011), "Küreselleşme, Büyüme ve Ekonomik Entegrasyonlar: Türkiye Açısından Bir Değerlendirme", Iktisat Fakültesi Mecmuası, Cilt: 61, Sayı:2, 3-22.

- İncekara, A., Savrul, M.(2012), "The Effect Of Globalization On Foreign Trade And Investment In Eurasian Countries", International Conference On Eurasian Economies 2012, 23-30, Almaty, KazakistanRepublic (October, 11th-13th 2012).

- $\quad$ Kirzner, I. M. (1973), "Competition and Entrepreneurship", University of Chicago Press, USA.

- $\quad$ KOF Swiss Economic Institute, (2013), "KOF Index of Globalization", Zurich.

- $\quad$ Lingelbach, D.C., De La Vina, L., Asel, P. (2005), "What's Distinctive about Growth-Oriented Entrepreneurship in Developing Countries?", UTSA College of Business Center for Global Entrepreneurship Working Paper No. 1.

- $\quad$ M. D. Intriligator (2003), "Globalization Of The World Economy: Potential Benefits And Costs And A Net Assessment", Policy Brief No:33, Milken Institute, Los Angeles.

- McKinnon A. (2003), "Entrepreneurship and Globalisation, A Literature Review", <http://homepages. inspire.net.nz/ jamckinnon/business/Entrepreneurship\%20and\%20Globalisation\%20$\% 20 \mathrm{~A} \% 20$ Literature\%20Review.pdf>.

- Miotti, L., Sachwald, F. (2006), "Old Economy in the New Globalization Phase", IFRI Reports, Institut Français des Relations Internationales, France.

- Schumpeter, J. A. (1934), "The Theory of Economic Development", Harvard University Press, Cambridge.

- Shangquan, G. (2000), "Economic Globalization: Trends, Risks and Risk Prevention", Economic \&Social Affairs, CDP Background Paper No. 1, ST/ESA/2000/CDP/1.

- Vinig, T., Kluijver, J. de (2007), “Does Globalization Impact Entrepreneurship? Comparative Study of Country Level Indicators”, Sprouts: Working Papers on Information Systems, 7(8). University of Amsterdam, Netherlands.

- Zahra, S.A., Rawhouser H.N., Bhawe, N., Neubaum, D.O., Hayton, J.C. (2008), "Globalization of Social Entrepreneurship Opportunities", Strategic Entrepreneurship Journal, 2: 117-131. 